\title{
Gonidium Production in Azotobacter chroococcum
}

\author{
By K. A. BISSET AND C. M. F. HALE-MCCAUGHEY \\ Department of Virology and Bacteriology, University of Birmingham
}

(Accepted for publication 3 February 1967)

SUMMARY

Electron microscopy of sections of Azotobacter chroococcum show that gonidia $c .0 .05 \mu$ are produced by or near the cell envelopes, increasing in size to $c$. $1 \mu$ and filling the lumen of the cell before release, which occurs by rupture of the envelopes.

\section{INTRODUCTION}

Reproduction of various bacterial genera by the release of motile gonidia has been recognized since the paper by Beijerinck in 1888; the process was described, by the use of stained preparations, phase-contrast and electron microscopy of entire organisms in Rhizobium by Bisset \& Hale (1951), in Azotobacter by Bisset \& Hale (1953), in Spirillum by Pease (1956) and in Bacillus by Bisset \& Hale (1963). General descriptions have been given by numerous workers, mainly of these same genera. Because of the exceedingly small size of the gonidia, and the electron-opacity of bacterial cell walls, convincing detail has been hard to obtain. The object of the present work was to attempt to overcome these problems, by using the technique of electron microscopy of ultra-thin sections. Sections of the gonidial swarmers of Bacillus cereus were obtained by Bisset (1966), but the mode of formation was not demonstrated, and sections through what were probably developing gonidia of spirochaetes were illustrated by Bladen \& Hampp (1964).

This type of reproduction is, of course, a commonplace among other types of flagellate protista; its theoretical importance in bacteria was pointed out by Bisset \& Hale (1963) and by Bisset (1966), who suggested that it might represent the primitive state of the process whereby L-forms and possibly mycoplasma are produced in structurally degenerate genera.

\section{METHODS}

Two strains of Azotobacter chroococcum, isolated in this laboratory, were cultured in the fluid medium described by Bisset \& Hale (1953). Old samples were examined microscopically between 4 and 6 weeks for signs of gonidium production. Suitable cultures were prepared and examined, as described by Bisset (1967).

\section{RESULTS}

Mother-cells in an early stage of gonidium production were only slightly larger than the vegetative forms. They appeared partially empty, with a thick wall on or near which the gonidia, about $0.05 \mu$ in diameter, were situated (P1. 1, figs. 1-3). There was much unidentifiable debris both within and outside such forms. Larger mother-cells, presumably near maturation, were less commonly seen, and were $10 \mu$ or more in 
diameter, containing fully developed small-phase vegetative forms (Bisset \& Hale, 1953; Bisset, 1967). These were about $1 \mu$ in diameter, were detached from the envelopes and appeared to fill the lumen of the mother-cell (Pl. 1, figs. 5, 6). Some mothercells contained large (lipid?) vacuoles also (Pl. 1, fig. 4). Frequently, the latter stages were represented by disrupted cell walls, associated with debris and a few small forms (P1. 1, fig. 4).

\section{DISCUSSION}

The evidence provided by electron microscopy of ultra-thin sections of Azotobacter shows that gonidia develop within the lumen of specialized mother-cells, as described from stained preparations by Bisset \& Hale $(1951,1953)$, and confirms the role of the cell envelopes in the formation of the new material, as suggested by Bisset \& Hale (1951). The size of the early stages is so small that, even by the ultra-thin section technique, they show little or no structure, but the mature gonidia or small vegetative forms (Bisset \& Hale, 1953; Bisset, 1967) are manifestly small bacteria. Earlier studies (Bisset \& Hale, 1953) show them to have polar flagella in common with all other known bacterial gonidia. Apart from the nitrogen-fixing genera, Azotobacter and Rhizobium, gonidia have been properly demonstrated in Bacillus and in spiral bacteria, and according to the theory of bacterial evolution suggested by Bisset (1962) these are all relatively primitive bacteria. Indeed, gonidium-formation may reasonably be regarded as a primitive character in bacteria, linking them with an ancestral form, little removed from other flagellate protista.

\section{REFERENCES}

BeiJerinck, M. W. (1888). Die Bakterien der Papilionaceenknöllchen. Bot. Ztg. 46, 725. (Translated in Brock, T. D., Milestones in Microbiology, 1961. London: Prentice-Hall Int. Inc.)

Bisser, K. A. (1962). The phylogenetic concept in bacterial taxonomy. Symp. Soc. gen. Microbiol.12, 361.

Bisset, K. A. (1966). Ultrastructure of the cell envelopes of the swarmers of Bacillus cereus. G. Microbiol. 14, 5.

Bisset, K. A. (1967). Ultrastructure of cell envelopes of large cells, small cells and cysts of Azotobacter chroococcum. J. gen. Microbiol. 48, 25.

BisseT, K. A. \& HALE, C. M. F. (1951). The production of swarmers in Rhizobium spp. J. gen. Microbiol. 5, 592.

Bisset, K. A. \& Hale, C. M. F. (1953). The cytology and life-cycle of Azotobacter chroococcum. J. gen. Microbiol. 8, 442.

Bisset, K. A. \& Hale, C. M. F. (1963). The swarmers of Bacillus cereus. J. gen. Microbiol. $31,281$.

BlADEN, H. A. \& HAMPP, E. G. (1964). Ultrastructure of Treponema microdentium and Borrelia vincentii, J. Bact. 87, 1180.

PeASE, P. E. (1956). The gonidial stages of Spirillum spp. and Vibrio spp. J. gen. Microbiol. 14, 672.

\section{EXPLANATION OF PLATE}

\section{All electron micrographs of unstained sections}

Figs. 1, 2. Adjacent sections through cell in early stages of gonidium formation, showing very small bodies, mainly attached to, or near, the cell envelopes. Comparison of figs. 1 and 2 shows that they are short and randomly arranged. Sections through two small cells appear below. $\times 14,000$.

Fig. 3. A slightly more advanced mother-cell showing some larger bodies. $\times 21,000$.

Fig. 4. Burst wall of mother-cell, with debris and small cells (i.e. mature gonidia). $\times 14,000$.

Figs. 5, 6. Mature mother-cells containing well-formed gonidia, resembling small bacteria; also a few (lipid?) globules and debris. Gonidia are no longer attached to the cell envelopes, but lie in the lumen of the enlarged cell. A few large vegetative cells are seen for comparison. $\times 7,000$. 

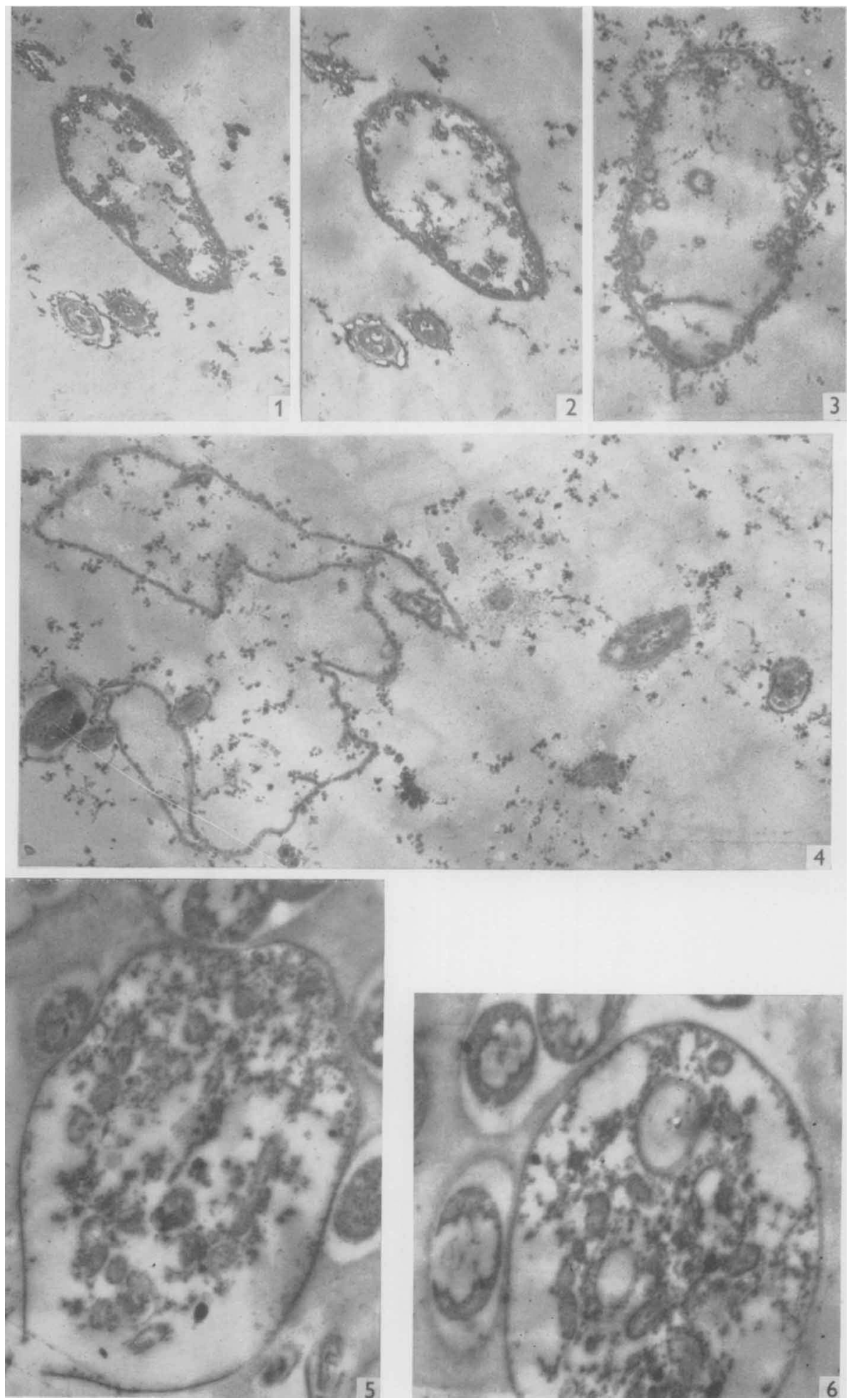